\title{
Incidence of Guillain-Barré syndrome among Zika virus infected cases: a report from Thailand
}

Incidência de síndrome de Guillain-Barré em pacientes infectados pelo vírus Zika:

um relato da Tailândia

Dear Editors,

Zika virus infection, at present, is a global public health problem. The neurological complications of Zika virus infection are very interesting. Guillain-Barré syndrome is an important complication that is widely reported ${ }^{1}$. Here, the authors summarize and report on the incidence of Guillain-Barré syndrome among Zika virus infected cases in Thailand. To-date (August 2017), there have been 1,417 accumulated patients with
Zika virus infection and there are two patients (0.14\%) with Zika virus-related Guillain-Barré syndrome. This rate is considerable lower that those previously observed in Polynesia and South America ${ }^{1,2}$. These data confirm that the neurological problem of Zika virus infection is not a significant problem in Thailand ${ }^{3}$. The mild nature of Zika virus infection in Thailand and tropical southeast Asia is an interesting topic for further studies.

Beuy Joob $^{1}$, Viroj Wiwanitkit ${ }^{2}$

\section{References}

1. Araujo LM, Ferreira ML, Nascimento OJ. Guillain-Barré syndrome associated with the Zika virus outbreak in Brazil. Arq Neuropsiquiatr. 2016;74(3):253-5. https://doi.org/10.1590/0004-282X20160035

2. European Centre for Disease Prevention and Control. Rapid risk assessment: Zika virus infection outbreak, French Polynesia: 14 February 2014. Stockhom: European Centre for Disease
Prevention and Control; 2014 [cited 2017 Aug 20]. Available from: http://ecdc.europa.eu/en/publications/Publications/Zika-virusFrench-Polynesia-rapid-risk-assessment.pdf

3. Wiwanitkit V. Guillain-Barré syndrome and Zika virus infection. Arq Neuropsiquiatr. 2016;74(8):692. https://doi.org/10.1590/0004-282X20160089 